\title{
Danish risk management plans of the EU Floods Directive
}

\author{
Martin Jebens $^{1, a}$, Carlo Sorensen ${ }^{1,2}$ and Thorsten Piontkowitz ${ }^{1}$ \\ ${ }^{1}$ Danish Coastal Authority, Coast \& Climate, Lemvig, Denmark \\ ${ }^{2}$ Technical University of Denmark, DTU Space, Kgs. Lyngby, Denmark
}

\begin{abstract}
We evaluate the impact and effect of the EU Flood's Directive (2007/60/EC) in Denmark and the flood risk management plans that are the result of the national implementation. In a qualitative research approach, the flood risk management plans published by 22 Danish municipalities are reviewed and analyzed regarding main objectives and structural and non-structural mitigation measures. From the analyses conclusions are drawn on the non-structural risk management measures still to be improved to obtain the full benefits from the Directive. Conclusions point to the need of introducing better decision support systems, a need to define acceptable risks, and a need to enhance coordination between municipal and cross-sectorial actors as well as an increased effort to involve civil society is necessary. In general, the implementation of the Directive has significantly advanced the national scientific and cross-sectorial working platform for dealing with risks from floods.
\end{abstract}

\section{Introduction}

By the end of 2015 the implementation of the first 6 year plan period of the EU Floods Directive (2007/60/EC) [1] has potentially led to improved disaster risk reduction and preparedness measures in all member states and to cross border actions.

After incorporation of the Directive into Danish legislation [2-4] and based on a preliminary flood risk assessment (2010-2011), 10 Danish risk areas were appointed due to potential flooding from storm surges and/or extreme river runoff [5-6]. The screening, appointment, and reporting was carried out in the geographical units of 'river basin districts' and 'river basins' according to the EU Water Frame Directive (WFD) (2000/60/EC) [7], Figure 1. This work was carried out by a workgroup from the Ministry of the Environment, mainly the Nature Agency (NA) with the responsibility of inland waters and the WFD, and the Ministry of Transportation represented by the Danish Coastal Authority (DCA) with coastal protection responsibilities.

A flood risk assessment (2012-2013) identified tangible and intangible losses as a consequence of extreme events today and under 2050 and 2100 climate scenarios for the 10 risk areas [8]. Here, in close collaboration between the DCA and the German Leichtweiß-Institute for Hydraulic Engineering and Water Resources at TU Braunschweig (LWI), the XtremRisk 'cellbased risk assessment' (CRA) method and mapping based on a 'Source - Pathway - Receptor' (S-P-R) approach [9-11] was further developed for Danish conditions [8, 12-13]. Subsequently, hazard, vulnerability and risk maps have been incorporated into risk reduction and risk management plans by the involved 22 municipalities in the 10 risk areas in 2014-2015 (Denmark is divided into 98 municipalities of which 76 have a coastline).

Whereas the appointment of risk areas and the risk assessment and mapping were carried out by DCA and the Nature Agency, the municipalities were responsible for producing the risk management plans in accordance with the Directive. The published overall plans by DCA in December 2015 [14-15] contain links to the individual municipality level plans, as well as to a GIS-solution showing all the maps produced in the hazard and vulnerability analyses and risk assessments [16], Table 1.

The paper presents some of the challenges faced and learnings gained from the first plan period of implementation of the EU Floods Directive in Denmark (2010-2015) with special attention given to the crosssectorial collaboration and coordination between science, national authorities and municipalities in the preparation of risk management plans. The implementation and transformation process of the produced risk maps into risk management and risk reduction plans at the municipal level is presented. Here, the emphasis is on the different approaches taken and challenges met in relation to legislation and to local physical/geographic, demographic, and municipal structural differences and conditions.

\section{Background and methods}

We start by summarizing details of the first two phases (2010-2011 \& 2012-2013) considered important to the

\footnotetext{
a Corresponding author: mje@kyst.dk
} 
overall understanding of the implementation of the Directive in Denmark and then present in more detail the $3^{\text {rd }}$ phase implementation of risk management plans by the involved municipalities.

\subsection{Past floods and appointment of risk areas}

Denmark has no large rivers and no previous accounts of floods comparable in any way to those experienced elsewhere in Europe over the past decades. Heavy precipitation and cloudbursts are generally seen as very local flood hazards. Much of the country's 7,300 km coastline is low-lying and despite many accounts of storm surges in the past, coastal flood protection schemes along the North Sea coasts and other coastal stretches mean that no lives have been lost due to sea floods in the past century [6]. However, the November 1872 Baltic Sea surge [17-20] stands out with its extremely high water levels that drowned 80 persons in Denmark alone.

In the screening and appointment of the risk areas, the 1872 extreme water levels were taken into account for relevant coastal stretches together with an additional 7 historic storm surge events to account for the potential coastal flooding along the entire Danish coastline. The contribution from sea level rise (SLR) due to climate change was also considered. Due to the uncertainty in projections and climate scenarios, as well as for political reasons (Denmark has no 'official' SLR numbers decided upon for planning and adaptation), a medium-term SLR of $30 \mathrm{~cm}$ was used with the uncertainty assigned to the timeframe. 2060 was used as year of reference, however, to include net land uplift from glacial isostasy. One important assumption made in the screening was that existing flood protection (dikes, dunes, seawalls etc.) was functional as long as the extreme water levels did not exceed the height of the protection measures. Regarding river floods, historic data and accounts of previous floods are in general scarce except for floods in the towns of Holstebro, Vejle, and Randers - areas included in appointed risk areas, and an additional few locations.

In the Danish approach it was decided that risk areas should consist of coherent units containing both a certain minimum real estate value of properties potentially getting flooded and a certain number of addresses within this area. The thresholds were eventually politically determined at 2 billion DKK (265 million $€$ ) and 500 addresses, respectively [5] yielding a total of nine risk areas (Koege Bay consisted of several units satisfying the thresholds and was consequently gathered in one risk area with a later subdivision for modelling purposes etc.). The $10^{\text {th }}$ risk area, Fredericia, was appointed succeeding the public hearing phase due to the presence of a flood prone power plant and high-risk chemical plants. Interestingly, the municipalities that did provide a reply to the public hearing all were in favour of becoming appointed as a risk area. Those municipalities that were preliminarily included in a risk area, although some questioned why they were selected in favour of other areas, were positive. The remaining replies from municipalities not appointed all indicated that they were in favour of becoming appointed. Apart from questioning the methods applied, one obvious reason was that these municipalities, too, were interested in having their flood risk assessed and mapped [21]. The Directive's implementation was thus positively perceived and welcomed by the municipalities.

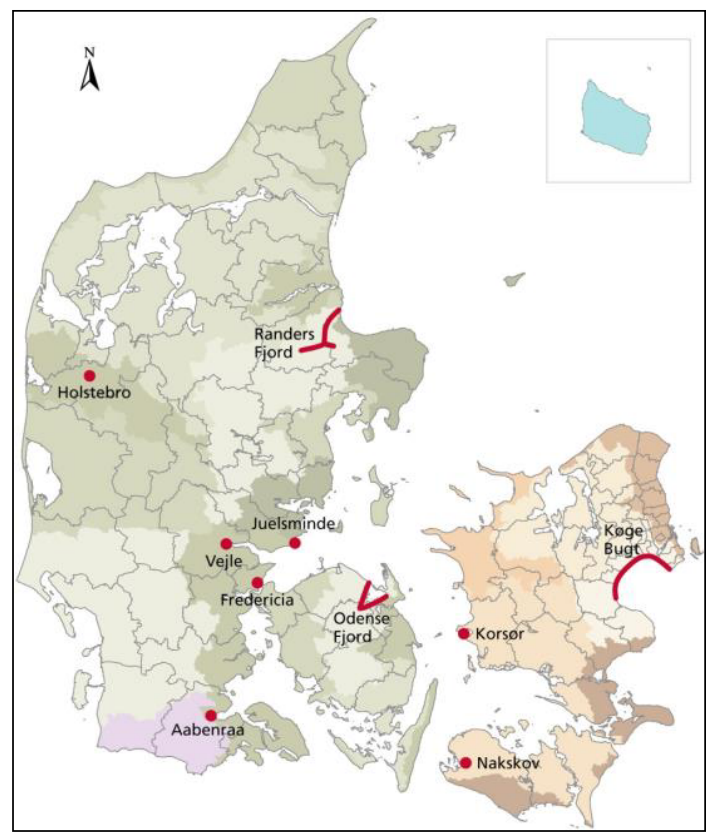

Figure 1. Map of Denmark showing the 10 risk areas (in red) appointed according to the EU Floods Directive. Colours (violet, green, brown, blue) show the Danish division into water basin districts with a subdivision into water basins shown by shades of colour.

\begin{tabular}{|c|c|c|}
\hline $\begin{array}{c}\text { Risk Area } \\
\text { web links to } \\
\text { GIS-maps }\end{array}$ & $\begin{array}{l}\text { Municipality } \\
\text { web links to risk } \\
\text { management plans }\end{array}$ & $\begin{array}{l}\text { Risk Source } \\
\text { Considered }\end{array}$ \\
\hline Randers Fiord & $\begin{array}{l}\text { Randers } \\
\text { Norddjurs }\end{array}$ & $\begin{array}{l}\text { Sea water \& } \\
\text { fluvial }\end{array}$ \\
\hline Juelsminde & Hedensted & Sea water \\
\hline Vejle & Vejle & $\begin{array}{l}\text { Sea water \& } \\
\text { fluvial }\end{array}$ \\
\hline Fredericia & Fredericia & Sea water \\
\hline Aabenraa & Aabenraa & $\begin{array}{l}\text { Sea water \& } \\
\text { fluvial }\end{array}$ \\
\hline Odense Fiord & $\frac{\frac{\text { Odense }}{\text { Kerteminde }}}{\frac{\text { Nordfyns }}{(1 \text { common plan })}}$ & $\begin{array}{l}\text { Sea water \& } \\
\text { fluvial }\end{array}$ \\
\hline Korsoer & Slagelse & Sea water \\
\hline Nakskov & Lolland & Sea water \\
\hline $\begin{array}{l}\text { Koege Bay } \\
\text { Subarea } 1 \\
\text { Subarea } 2 \\
\end{array}$ & 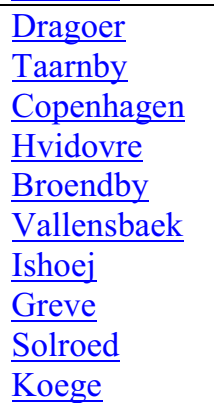 & $\begin{array}{l}\text { Sea water \& } \\
\text { fluvial }\end{array}$ \\
\hline Holstebro & Holstebro & Fluvial \\
\hline
\end{tabular}

Table 1. Overview of the 10 Danish risk areas and the affected municipalities within each area. The risk areas have been appointed due to either a risk of flooding from the sea (4 areas), from streams/rivers (1) or a combination (5). 


\subsection{Flood Risk Assessments and Mapping}

Apart from local area studies by the DCA [22-25] there was little practical experience with flood risk assessments in Denmark prior to the implementation of the Directive. In this aspect the need for the development and implementation of a general, yet consistent method to fulfil the Directive on the national level was obvious, and the work had to be carried out within a relatively limited time scale and economic frame. The present authors were also aware that this process of development would extend beyond the first plan period, and that a selective choice regarding the theory and methodology of risks and risk assessments complying with available data was necessary.

A joint collaboration project was initiated between LWI and DCA as previously mentioned. Through this project, 'Hazard and Risk Mapping in Denmark' (HARIMA-DK), the research results and methodologies of XtremRisk were applied on a wider scale in Denmark, and it serves as a good example of a science-government project that successfully i) transfers research into societal use, ii) increases the national knowledge foundation regarding risk assessments and risk mapping, and iii) transfers practical experience of application back into academia. Following a 6-step framework a hazard analysis containing determination of hydraulic boundary conditions, reliability analyses, and inundation modelling; a vulnerability analysis evaluating tangible and intangible losses, and a flood risk assessment was carried out in each of the 10 risk areas. Correspondingly, hazard, vulnerability and risk maps were produced and delivered to the municipalities.

Throughout the production phase (2012-2013) the DCA built a close contact to the involved municipalities, e.g. by hosting bilateral meetings and establishing personal contacts to secure that the maps as rightfully as possible represented local conditions; to transfer knowledge about risk and methods applied to the municipalities; to inform about the municipal tasks in the third phase of implementation, and to gain knowledge about the municipal structure in each of the municipalities involved. The risk areas vary considerably in geographical extent and the number of municipalities involved (cf. Table 1), as well as the risk source(s) and severity of potential floods show large differences. In addition, the municipalities were at different climate adaptation planning levels. To assist the municipalities guidelines on risk management plans were published [26], which is treated further below.

As maps were produced for 6 flooding scenarios, 2 hazard, 7 damage and 2 risk categories, respectively, in 5 grid cell sizes, this has provided DCA and LWI much information about the method's performance. This horrendous number of maps was, of course, reduced for practical use in the municipal risk management plans. At municipal meetings the maps were presented by DCA and discussed in order to select maps to appropriately fit municipal needs and varying technical solutions; to incorporate prior knowledge about flood hazards and risks, and to merge the maps with existing data sets within the municipalities.

\subsubsection{Municipal climate adaptation plans}

Subsequent to the appointment of risk areas, the then new national government (elections were held in September, 2011) put forward legislative acts whereby all municipalities should make climate adaptation plans by the end of 2014 and integrate these into the overall municipal planning in the auspice of the Nature Agency [27-28]. The plans mainly focus on floods from cloudbursts and the sewer systems (sewer systems were not a part of the Danish implementation of the Directive) and do not deal with climate adaptation in a broader sense, however. Thus, the municipalities covered by the risk area appointment simultaneously had to make climate adaptation plans for their entire land area as well as a risk management plan for the part covered by the Directive.

The work on municipality climate adaptation plans understandably led to some confusion about their relation to the Directive but, without discussing the content, context, and timing of the adaptation plans further here, many municipalities have undoubtedly prospered from the knowledge gain and methodologies of the Directive's implementation in carrying out their climate adaptation tasks and vice versa, and some merging of 'climate adaptation' from national legislation with the legislation of the Floods Directive is anticipated for the second plan period (2016-2021). As municipal plans, now including also climate plans, are revised every four years and the Directive works with 6 year plan periods, this means that plan revisions are concurrent every $12^{\text {th }}$ year. Apart from this lack of synchronization of the Directive with municipal level planning, there has been little conflict with national legislation. Issues regarding flood protection measures and permissions lie mainly within the Danish legislation.

\subsection{Methods for risk management plan review}

The risk management plans from the two water basin districts, Jutland and Zealand [14, 15], Table 1, are reviewed in order to get an overview of objectives contained in each plan. The review analyses whether the risk management plans fulfil the criteria given by the guidelines to support the municipalities in formulating plans [26] to meet the legal binding of the Directive.

In addition, the different mitigation/adaptation measures intended, priorities of the plans, and set-up to monitor progress of implementation is investigated. The purpose of the review is not to control whether the municipalities fulfil the Directive but to document the process and gain knowledge for improving the work ahead. Collaboration between neighbouring municipalities within risk areas and across water basins has been investigated, too. From this, and from the authors' work with the Directive and the involved municipalities over the past years, we seek to identify matters unaccounted for in the Danish implementation of the Directive regarding legislation, methodologies, collaboration, information etc. To support the findings semi-structured interviews were conducted with the local emergency 
management and administration from two municipalities, respectively, one in each water basin district [29].

The preparation of risk management plans builds on a multi-layer concept with emphasis on preventionprotection-preparedness [30]. The risk management plans must use the hazard, vulnerability and risk maps prepared and provided by DCA and the Nature Agency. The plans should be coordinated with the abovementioned municipal climate adaptation plans and take into account climate change impact on floods. According to the UNISDR [31] disaster risk management can be understood as: "The systematic process of using administrative directives, organizations, and operational skills and capacities to implement strategies, policies and improved coping capacities in order to lessen the adverse impacts of hazards and the possibility of disaster". In this risk management forms a crucial part. It includes risk assessments and analysis, and the implementation of guidelines and policies to decrease, control or transfer risks. It is highly linked to preparedness planning which is based on comprehensive analyses of disaster risk. In contrast to risk management plans, preparedness plans have to take into account a much broader set of outcomes in both the risk reducing, response and recovery phases. This would include information management, national institutional legislation frameworks, coordination, contingency planning, capacity analysis, emergency services, and incorporate early recovery and recovery. Coordination between the involved stakeholders is therefore of great importance.

The municipal risk management plans are related to risk mitigation and adaptation but should still fulfil a number of minimum criteria and from the maps provided by DCA conclusions shall be drawn. Minimum criteria have to be identified in order to secure that agreed goals are achieved. Objectives and proposed measures to achieving these goals have to be stated by the municipalities together with a detailed description on the timing of implementation and of the stakeholder responsibilities. Finally, to monitor the process a description on how the implementation will be audited should be developed. According to the guidelines [26] the main objectives should be to reduce the adverse flooding impact on the health of the civil society, the environment, cultural heritage, and economical activities through mitigation and adaptation measures. The guidelines suggest that risk management planning should emphasize on cross-coordination between actors in the municipality and across municipalities and river basins. In addition, the guidelines recommend the inclusion of civil society.

\section{Risk management plan review}

22 Danish municipalities have made their first risk management plans targeting floods and have started analyzing the challenges faced. The main findings from the review of the municipal risk management plans are tabulated in Table 2. For each of the risk management plans the analysis looks into their content regarding main objectives, precautionary measures, and structural and non-structural mitigation measures. Regarding the latter, emergency management and preparedness planning are stated separately. This is done to contrast the planning initiatives to more tangible measures implemented in emergency management by the municipalities.

\subsection{Main objectives}

The review shows that only three out of 20 municipal risk management plans explicitly mention the four main objectives: people (civil society), environment, cultural heritage, and the economy. Whereas most of the plans mention some of the main objectives from the governmental guidelines [26], a couple of the plans completely lack this connection. The guidelines do not give a clear definition of the objectives, however, and overlaps or gaps may be included, e.g. that preventing damage on private property can be taken into account in 'people' or 'economy'. Many municipalities have an overarching goal to secure their area from flooding, but it is often not possible to see whether and which of the main objectives are included in their work.

\subsection{Precautionary measures and emergency management}

Besides the main objectives the guidelines also call for information on priorities of the initiatives, on the prevention and protective measures (structural and nonstructural), and on the inclusion of emergency management. Almost all municipalities identify the need to improve emergency management and work towards improving potential responsive actions. The priority and ranking of mitigation and adaptation projects are in many cases well established. A few municipalities have not stated priorities for, or, have no well-defined objectives or measures established. This may lead to duplicated work and/or gaps since the involved stakeholders are likely to be unsure about their responsibilities. None of the municipalities mentions improved preparedness plans for the emergency management. This task is of great importance because of the interactions between risk management plans and preparedness plans, however. In addition, a review of selected municipal preparedness plans reveals that these are not well developed, and the lack of planning can potentially lead to failure during a flood event. The emergency managements are to some extent aware of this. Furthermore, they are in some cases of the opinion that in the event of extreme floods, they will not be able to cope [29].

All municipalities have protective measures incorporated and most plans also contain preventive measures. The measures focus on both structural and non-structural mitigation and adaptation, but there is a strong tendency towards structural mitigation and these clearly outnumber the non-structural measures. In addition, ideas for structural measures tend to be much further developed and better described. Among nonstructural mitigation measures cooperation between different stakeholders and across municipality borders and river basins has a strong focus. 


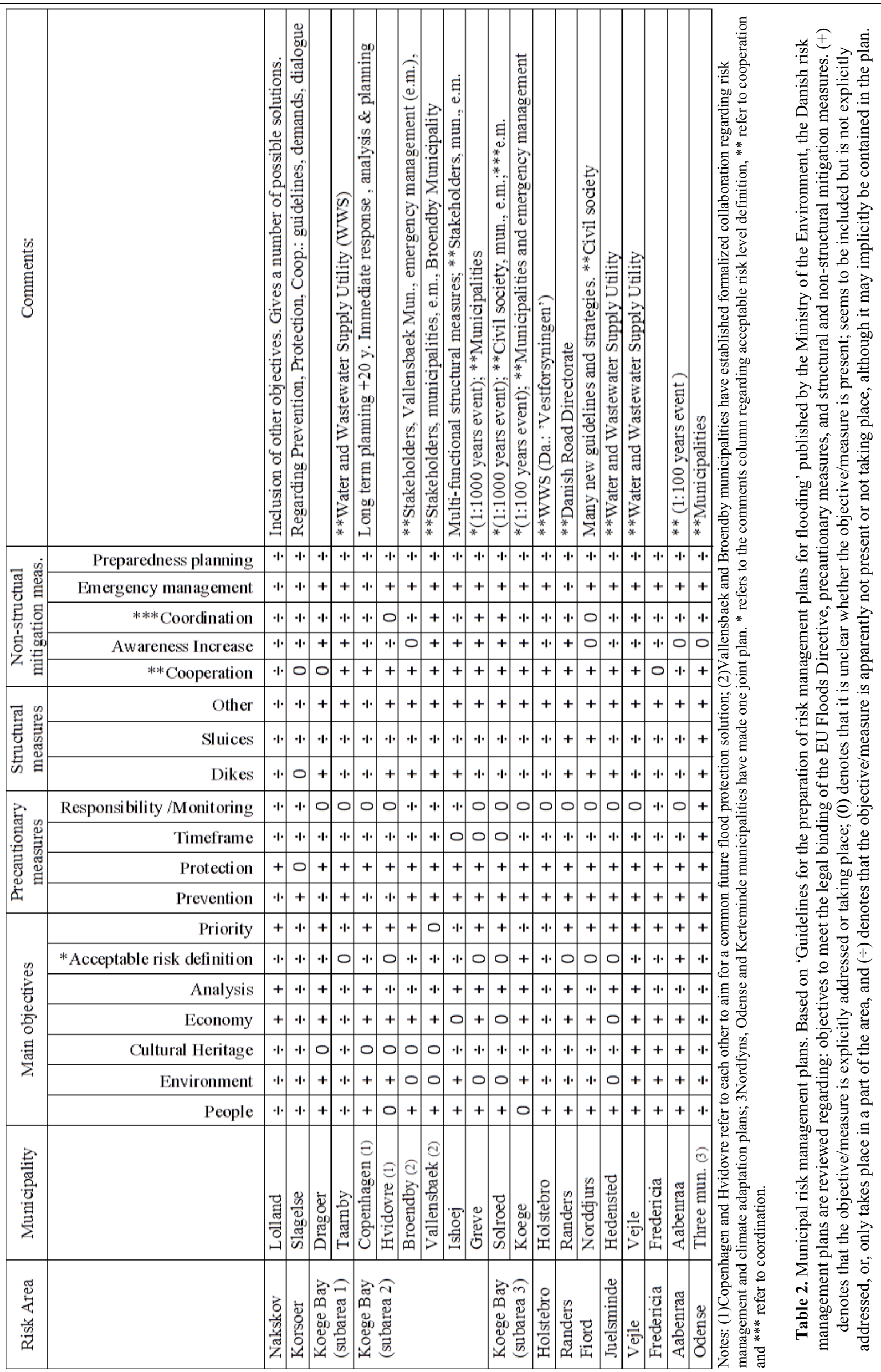


Unfortunately, there are generally only vague indications of how this collaboration and coordination is to take place and by whom. One issue not revealed in Table 2 is a strong focus on producing new guidelines/frameworks/ policies in most municipalities. This is a good first step but has to be followed up by an awareness increase. The risk management plans to some extent include awareness increase among the civil society and businesses owners. However, awareness increase is often limited to subareas and is not distributed across the entire risk area. In this sense, many municipalities signal that the iterative process of risk management through collaboration, public and stakeholder engagement and awareness increase is slowly forming.

Analyses of future problems and challenges are key elements of all risk management plans. This will give each municipality time to analyze both positive and negative consequences of protective measures as well as time to create sound solutions.

\subsection{Collaborative efforts}

The implementation of the Directive is a new task to the involved municipalities and they each have to find their own viable way forward with respect to their political situation and administrational organization. Whereas a flood 'that crossed municipal borders' came as a surprise to some municipalities a few years ago, they are now increasingly becoming aware that collaboration across municipal borders is necessary and beneficial. In the first plan period, most probably due to lack of time and resources, most municipalities have sought to 'guard their own back yard' in the preparation of their management plans assisted by external consultants. Most municipalities do want to collaborate ahead as indicated in their plans, however.

The three municipalities within the Odense Fiord risk area have worked together and produced one common and shared plan. Although their individual parts of the risk area vary regarding size, vulnerability and risk, the municipalities acknowledge that they 'more or less face the same hazards and depend upon each other to reach both individual and common risk reduction measures' [32]. The Odense Fiord risk management plan pays little attention to the main objectives (although they may be inherited in the plan) but has a strong focus on information, public involvement, and local capacity building. This way the plan contrasts most of the other plans by choosing another starting point for reducing the risks from flooding.

Collaboration is made between municipalities and with stakeholders in each municipality, but it is still unclear in the risk management plans whether this results in coordination and how the coordination is taking place. Neither central organizations nor responsible persons are mentioned as a part of the coordinating work. As coordinating actions are difficult to control without a governing body this is a drawback of the risk management plans. A lack in coordination was also identified from interviews [29].

\subsection{Responsibility and monitoring}

Most municipalities either have the municipal organization assigned as the responsible unit or do not refer to any responsible body. Only the municipalities within the Odense Fiord risk area have clearly stated responsible partners. Also, the monitoring process is poorly described in all plans. Intermediate deliveries cannot be identified from the plans, nor is the process described on how the work will be conducted. Timeframes for implementation of the different projects and measures are also insufficient. Again, there is no information about when deliveries will be implemented. According to the Directive the measures included in the risk management plans have to be finalized within the next six years, and this is thus the overall timeframe for work in most of the plans.

In any work, monitoring and responsibility of the process is crucial to make sure goals and deliveries are met to the agreed quality and time. It is therefore important that different partners agree on the goals as well as responsibility of deliveries and the monitoring regime. This process is not very well described in any of the risk management plans.

\subsection{Acceptable risk}

Besides the main recommendations given by the government guidelines, the analysis also identifies the level of protection the municipalities are aiming at; the accepted risk level.

The accepted risk level or level of service is often not given. This is also supported by the semi-structured interviews [29]. A number of municipalities have initiated a process analyzing their needs and some have defined an acceptable risk level as a minimum probability of occurrence, or, as a minimum height of protection. From the risk management plans it can be concluded that cost-benefit analyses have not been made or implemented so far. This makes a proper the decision-making process difficult and may result in suboptimal mitigation and adaptation measures.

Basically, neither the municipalities considered nor the Danish Coastal Authority have prior experiences working with risk acceptance for large areas as in the context of the Directive, and the work on addressing risks and the process of defining and determining acceptable risk levels in a risk based framework is, indeed, still in its infancy at all governance levels.

\section{Discussions}

"Flood risk management should always be done collectively ... and the development of effective institutions are crucial to implement good risk reduction" World Bank, 2012 [33]

\subsection{Overall implementation of the EU Floods Directive in Denmark}

Discussions about duly implementation and over- or under-implementation of EU Directives etc. are central in 
Danish national politics and administration as they are in other member countries. Over the past 6 years the status of the EU Floods Directive in Denmark has, in the authors' opinion, moved from being perceived as a minor addendum to the EU Water Frame Directive to become a driver for dealing with natural hazards and risks in Denmark. For several reasons, amongst other that no lives have been lost as a direct consequence of floods in a century, risk and risk perception in relation to floods has played an insignificant role in Denmark. Very little national work has previously dealt with risk assessments, risk mapping and risk management in relation to floods. Still, the risk of flooding is present, and the work on the implementation of the EU Floods Directive in Denmark has contributed to a national advancement in dealing with risks.

Within the framework of the EU Floods Directive there are several degrees of freedom in the national choice of approach and applied methodologies to achieve the main goal of reducing risks from floods. Denmark has followed one path from the preliminary assessment via the appointment of risk areas, to the hazard, vulnerability and risk assessment and mapping and to the formulation of risk management plans by the involved municipalities within each of the 10 Danish risk areas. The work has been carried out in an open process where, through the three phases of implementation, all materials have been revised and published based on public hearings; for the first two phases by the DCA and the Nature agency, and in relation to the risk management plans by the individual municipalities to meet the requirements of the Directive. Most of the methods applied and the "workflow" and cross-sectorial collaboration can be improved based on the experiences gained from the first plan period. This also means that the national approach to the appointment of risk areas and strategies to deal with risk may change ahead.

Municipal risk management plans are the overall result of implementation of the Directive, and initiatives and measures to reduce risks from flooding will mainly take place at the local level in the municipalities. For the Danish risk areas the 22 municipalities have all positively engaged in the process of implementation. A key to the success of the Directive in the Danish municipalities is its legal binding. The legislative framework of the Directive has been welcomed by all municipalities since it gives the possibility to create clear goals which politicians have to fulfil. The Directive enforces member states to identify current and future flood risks and prepare to mitigate them. Identification of the hazard, vulnerability and risk is crucial for well-informed decision-making but has to be followed up by risk management plans. Danish municipalities shall thus implement the suggested mitigating and adaptive actions in a 6 year timeframe.

The risk areas vary considerably in relation to the source of flooding, in their geographical and physical complexity and level of current protection (pathway), and in the urban structure (receptor). Also, the municipalities have different levels of experience and knowledge about floods, and are at different levels regarding climate change adaptation and dealing with flood protection. For instance, the town of Vejle (Vejle risk area) has experienced several floods from both rivers and the sea, and the municipality is currently aiming for large sluice and dike solutions. Here, the timing of the risk management plan makes it opportune. Hedensted (Juelsminde risk area) and Slagelse (Korsoer risk area) municipalities have also dealt with flood hazards and protection for a number of years. In the Koege Bay risk area, where very few people have actually experienced floods and existing flood protection measures have been in place for decades, some municipalities have not previously dealt with sea floods at all. For Copenhagen Municipality, often considered as a national 'first-mover' regarding climate change adaptation, the actual part being in the risk area is small and little attention is given in addition to measures already in place or planned for. Within Odense Fiord risk area various future solutions are being discussed, but the main focus is on the capacity building.

Comparability between the risk areas has not been assessed in detail. On focal point ahead is to secure, as far as possible, that risks can be compared between locations to provide for a more thorough national emphasis on risks, risk reduction and risk acceptance. The review of the risk management plans reveals that the municipalities have made their first steps towards dealing with risks from floods, however.

\subsection{Past flood risk management in Denmark}

Flood risk management should include the implementation of sustainable measures that target specific threats in an identified hazard area. Ideally, the measures should be accepted by the population to create local ownership of the process. The process should also identify the socio-economic consequences. This is often done by conducting a cost-benefit analysis. Danish municipalities are currently in a modus where solutions are sought for before identifying the real hazard, vulnerability and risk. Large structural adaptive measures have often been suggested to prevent future floods. Such preventive measures could have a profound negative impact on the environment, the socio-economic situation, or, they may transfer risk to adjacent areas. In addition, solutions have often been decided upon in the short aftermath of a storm surge and may be insufficient due to a lack of knowledge, or, because all relevant stakeholders are not included.

\subsection{Danish flood risk management plans}

Clear differences exist in the municipal risk management plans concerning the level of detail in the planned implementation of measures. Some municipalities use logic frameworks to give an overview on objectives, timeframes, responsible actors and monitoring. In contrast, other municipalities are less explicit on the goals and it is difficult to identify how the work will be carried out and monitored. In addition, not all municipalities divide mitigation and adaptation measures into a prevention-protection-preparedness framework. 
The risk management plans have a strong focus on structural compared to non-structural mitigation measures. This includes elevation of dikes or terrain, establishment of new dikes, establishment of water storages etc. Some measures are minor in order to prevent or delay flooding etc., whereas others are large. These large structures will not only keep water out of the area but may also influence the ability to remove water as a consequence of increased precipitation and a raised groundwater table. Large structural mitigation measures may therefore increase the risk. Non-structural (intangible) mitigation and adaptation measures are given less attention, e.g. in the form of preparedness planning. They will increase the capacity of the society to lower the impact from flood events and can provide better and less expensive solutions compared to structural mitigation measures. Two non-structural measures are present in many plans, however: especially regarding large projects there is a focus on analyses of the environmental and socio-economic impact. Also, there is focus on revisions of local emergency management plans. The emergency management plans are often found to be undeveloped and lack fundamental requirements to mitigate a flood disaster. In addition, local emergency management staff has not conducted training related to floods in the past [29]. An overall improved emergency management strategy and planning may contrast experienced national budget cuts over the past couple of years, however.

Ideas for mitigation measures are often given without explicit consideration to what the municipality is protecting itself against, and cost-benefit analyses are not conducted. There is a need for decision-support systems to deal with both structural and non-structural mitigation measures and to analyze the measures in relation to socio-economic conditions and the environmental impact. This need is identified by some Danish municipalities, too. The complexity of such a system may need trained end-users but will likely improve flood risk management in Denmark and target solutions to specific threats.

A few municipalities have defined an acceptable risk in their risk management plans. It is identified from the probability of the event, or, a defined topographic height and does not address the risk itself. As a starting point for decision-making and to learn about the risk in an area, it may be useful until more elaborate definitions are introduced. 'Although Denmark has the financial and technical solutions to prepare for future flooding, currently there is a lack of thinking ahead. It is important to accept the possibility of future flooding and prepare for it at an early stage even though it will lead to unpopular decisions' [29]. Some municipalities call for national guidelines or legislation that dictates the acceptable risk. It is through the iterative process of public involvement and debate that local political decisions currently have to be made, but the need for tools to deal with 'acceptable risk' is obvious. The difficulty in predicting future change also put pressure on local politicians and uncertainty often leads to a state of indecision. It can be difficult for politicians to prioritize costly flood protection measures for a future with different potential outcomes in relation to floods.
Awareness in the civil society has to be raised to improve mitigation. This is not achieving much attention in the risk management plans except for minor focus areas. Directives, frameworks and guidelines will not by themselves improve disaster risk management and mitigate the flood risk. Creating awareness is a continual process and cross-cutting in the way that it needs to take multiple issues into account. The lack of awareness towards floods should be seen in relation to other risks that are more urgent to many people like threats to life or economic problems, for instance. Awareness increase should therefore be linked to issues which are of greater concern to the impacted population. A part of the legal process to implement risk management plans in Denmark is the public hearing phase. The government guidelines [26] support the involvement of the civil society because it will increase ownership of the process, and this part should gain increased national focus in the second plan period of the Directive.

To adapt to risks under future climate change, coordination is needed on all levels and must be crosscutting. Most risk management plans only briefly emphasize on the importance of coordinating future work, and no examples describing how this work should be done were identified. However, the municipalities have collaborated across administrative borders and internally in the municipalities during the preparation of the risk management plans. For Odense Fiord risk area this has resulted in a shared plan between the three involved municipalities with ranked solutions. For the remainder of the plans, the lack of coordination in the implementation process is striking. The responsible or coordinating bodies are weakly defined; the monitoring process is not described, at the plans lack a timeframe. In addition, a lack of coordination and cross-cutting work between municipalities and governmental institutions has been identified. Flood risk management and climate change adaptation are generally resource demanding processes for which many of the municipalities have to reorganize to deal with the workload and the flood challenges. Above all, however, all municipalities have 'started their journey' into risk management through the implementation of the Directive, and they are all in the midst of finding each their way to deal with floods ahead.

To the Danish Coastal Authority and other relevant governmental institutions there is also a need to reconsider our tasks and ways of collaboration in relation to dealing with risks from flooding. A continuous collaboration with the abovementioned municipalities, as well as those that have not been appointed as risk areas under the Directive's first plan period, is essential in order to learn more about risks from flooding and to advance the way we perceive and deal with risks in Denmark.

\section{Conclusions}

Effects of the EU Floods Directive in Denmark are analyzed and reviewed with an emphasis on the preparation of flood risk management plans at the 
municipal level within the 10 Danish risk areas appointed in the first plan period of implementation.

In general, the collaboration and coordination between science, national authorities and municipalities in producing the hazard, vulnerability and risk maps has led to a successful incorporation, and it could be a key element to change the awareness among municipalities and the civil society. From a qualitative study conclusions are drawn on the non-structural risk management measures still to be improved to obtain the full benefits from the Directive. Conclusions point to the need of introducing better decision-support systems, a potential need for the national government to assist in defining protection criteria and acceptable risks, and a need for better coordination in order for mitigation measures to be implemented without gaps or duplicating work.

We conclude that, although vulnerability towards flooding in Denmark is usually considered low compared to other EU member states, the implementation of the Directive has led to substantial national advancements in our ways of perceiving, mapping and dealing with risks from flooding.

\section{Acknowledgments}

The authors wish to thank and acknowledge our colleagues at Leichtweiß-Institute for Hydraulic Engineering and Water Resources at TU Braunschweig for a fruitful collaboration in developing the XtremRISK methods to suite Danish conditions and data for implementation of the Directive in Denmark: Prof. Hocine Oumeraci, Prof. Andreas Kortenhaus (now Ghent University, B), Dr. Andreas Burzel (now Deltares, NL), David Schürenkamp. Futhermore, our former DCA colleague Marianne Skov is acknowledged for the MIKE21 hydrodynamic modelling in the risk areas. Finally, we would like to thank Louise Grøndahl from the Nature Agency for the long-lasting collaboration on the Directive, and colleagues in the involved municipalities are acknowledged for a very constructive dialogue throughout the implementation of the Directive. Cofunding for the work presented is provided by Innovation Fund Denmark (Grant no. 1355-00193).

\section{References}

1. EU (2007). DIRECTIVE 2007/60/EC of the European Parliament and of the council of 23 October 2007 on the assessment and management of flood risks. Official Journal of the European Union, L 288/27 (6/11/2007).

2. Danish Parliament (2009). Lov nr. 1505 af 27. december 2009 om vurdering og styring af oversvømmelsesrisikoen fra vandløb og søer, Danish Ministry of the Environment. Copenhagen. (Accessed 29 February 2016).

3. Danish Ministry of Transportation (2010). Bekendtgørelse nr. 121 af 2. februar 2010 om vurdering og risikostyring for oversvømmelser fra havet, fjorde eller andre dele af søterritoriet. Copenhagen. (Accessed 29 February 2016).

4. Danish Ministry if the Environment (2010). Bekendtgørelse nr. 1042 af 1. september 2010 om samarbejde mellem Danmark og Tyskland om vurdering og styring af oversvømmelsesrisikoen fra vandløb og søer $\mathrm{i}$ det internationale vanddistrikt. Copenhagen. (Accessed 29 February 2016).

5. Piontkowitz, T. and Sorensen, C. (2011). Forslag til udpegning af risikoområder på baggrund af en foreløbig vurdering af oversvømmelsesrisikoen fra havet, fjorde eller andre dele af søterritoriet. Technical background report, Danish Coastal Authority, Lemvig, Denmark. http://www.masterpiece.dk/UploadetFiles/10852/36/ Baggrundsrapport KDI april 2011(1).pdf

(Accessed 29 February 2016).

6. NA and DCA (2011). Endelig udpegning af risikoområder for oversvømmelse fra vandløb, søer, havet og fjorde. EU's oversvømmelsesdirektiv (2007/60/EF), Plantrin I. Nature Agency (NA), Ministry of the Environment, \& Danish Coastal Authority (DCA), Ministry of Transportation, Copenhagen, Denmark.

http://www.masterpiece.dk/UploadetFiles/10852/36/ Udpegning af risikoomr der NST-KDI(1).pdf (Accessed 29 February 2016).

7. EU (2000). DIRECTIVE 2000/60/EC of the European Parliament and of the Council of 23 October 2000 establishing a framework for Community action in the field of water policy. Official Journal of the European Union, OJ L 327 $(12 / 22 / 2000)$.

8. DCA (2013). Kortlægning af fare og risiko for oversvømmelse. Metoderapport. EU's oversvømmelsesdirektiv (2007/60/EF), plantrin 2. Danish Coastal Authority, the Ministry of Transportation, Copenhagen, Denmark. Retrieved 29 February 2016 from http://docplayer.dk/3969520-Kortlaegning-affare-og-risiko-for-oversvoemmelse.html

9. Burzel, A., Dassanayake, D. and Oumeraci, H. (2012). Spatial Modelling of tangible and intangible losses in integrated risk analysis - results of the XtremRisK project. Proceedings 2nd European Conference on Flood Risk Management, FLOODrisk2012, CRC Press, Rotterdam, The Netherlands, pp. 557-565.

10. Dassanayake, D.; Burzel, A.; Oumeraci, H. (2012): Intangible flood losses: methodologies for their evaluation and their integration in flood risk analysis. Proceedings 2nd European Conference on Flood Risk Management, FLOODrisk2012, CRC Press, Rotterdam, The Netherlands, pp. 585-590.

11. Burzel, A., Dassanayake, D. R. and Oumeraci, H. (2015). Spatial Modeling of Tangible and Intangible Losses in Integrated Coastal Flood Risk Analysis. Coastal Engineering Journal, 57(1) (2015) 1540008 (31 pages). DOI: 10.1142/S0578563415400082

12. Piontkowitz, T., Sorensen, C., Jebens, M., Schürenkamp, D, Burzel, A. and Kortenhaus, A. (2014). Hazard and Risk Maps for the EU Floods Directive in Denmark. Third Nordic International 
Conference on Climate Change Adaptation, Copenhagen, Denmark 25-27, August 2014.

13. Kortenhaus, A., \& Oumeraci, H. (2014). Flood risk assessments - results, applications and future requirements. Proceedings of 34th Conference on Coastal Engineering, Seoul, Korea, 2014. http://dx.doi.org/10.9753/icce.v34.management.15

14. DCA (2015). Risikostyringsplan for Vanddistrikt Jylland og Fyn - EU Floods Directive. Danish Coastal Authority and Nature Agency, Danish Ministry of Environment and Food (21 December 2015), Copenhagen.

15. DCA (2015). Risikostyringsplan for Vanddistrikt Sjælland - EU Floods Directive. Danish Coastal Authority and Nature Agency, Danish Ministry of Environment and Food (21 December 2015), Copenhagen.

16. DGA (2015). MiljoeGIS. Environmental public web GIS portal. Danish Geodata Agency with content by Danish Coastal Authority and Nature Agency. Danish EU Floods Directive maps accessible from: http://miljoegis.mim.dk/spatialmap?profile $=$ oversvo em2\&sessionid $=\{6$ B3999F7-A715-4223-91E8FA01BBD97038\} $\&$ http://miljoegis.mim.dk/fagtekster/miljoegisstatisk/oversvom 2/offentliggorelse af oversvommel sesdirektivet_2013.pdf (Accessed 29 February 2016).

17. Colding, A. (1881). Stormen over Nord- og MellemEuropa af 12te-14te November 1872 og over den derved fremkaldte Vandflod i Østersøen. Vidensk.Selsk.Skr, 6. rk., Naturvidenskabelig og Matematisk Afd. I. 4.

18. Baensch, O. (1875). Die Sturmfluth vom 12./13. November 1872 an den Ostseeküsten des Preussischen Staates. Zeitschrift für Bauwesen, 25, 156-220.

19. Jensen, J. and Töppe, A. (1990). Untersuchungen über Sturmfluten and der Ostsee unter spezieller Berücksichtigung des Pegels Travemünde. Deutsche Gewässer $\neg$ kundliche Mitteilungen DGM, Jahrgang 34, H.1/2.

20. Dahlberg, R., Albris, K. and Jebens, M. (2016). The Baltic Storm Surge in November 1872: Urban Processes, Gendered Vulnerability and Scientific Transformations. In Deborah Simonton and Hannu Salmi (eds.): Catastrophe, Gender and Urban Experience, 1648-1920. Routledge forthc. (In press)

21. NA (2011). Replies (in Danish) to Public Hearing on the appointment of Danish risk areas under the EU Floods Directive. Nature Agency, the Danish Ministry of the Environment, Copenhagen. http://naturstyrelsen.dk/media/nst/attachments/7574 1/hringssvar.pdf (Accessed 29 February 2016).

22. Piontkowitz, T., Kortenhaus, A., Oumeraci, H. and Munk-Nielsen, C.-C. (2006). Risk analyses of coastal flood defence systems: Experiences and research challenges from two case studies. Proceedings $30^{\text {th }}$ International Conference Coastal Engineering 2006 (ICCE), Vol. 2, San Diego, U.S.A., pp. 1740-1752.
23. DCA (2006). Risikoanalyse af en klitbeskyttet kyst. Technical Report. Danish Coastal Authority, Lemvig, Denmark.

http://www.masterpiece.dk/UploadetFiles/10852/25/ klit rapport alt.pdf (Accessed 29 February 2016).

24. DCA (2004). Risk Assessment for the Wadden Sea. COMRISK, Subproject SP 7. Danish Coastal Authority, Lemvig, Denmark.

25. Piontkowitz, T., Oumeraci, H. and Kortenhaus, A. (2005). Risk Assessment for the Ribe Area COMRISK Subprojekt 7. Die Küste, 70, 87-102.

26. Ministry of the Environment (2014). Vejledning til udarbejdelse af risikostyringsplaner for oversvømmelse. Nature Agency and Danish Coastal Authority, Ministry of the Environment, Copenhagen.

http://www.klimatilpasning.dk/media/826542/vejled ning risikostyringsplaner.pdf (Accessed 29 February 2016).

27. Danish Government (2012). Sådan håndterer vi skybrud og regnvand - Handlingsplan for klimasikring af Danmark. Danish Government, Copenhagen.

http://naturstyrelsen.dk/media/nst/Attachments/Klim ahandlingsplan_dec_2012.pdf (Accessed 29 February 2016).

28. Nature Agency (2011). Klimatilpasningsplaner og klimalokalplaner. Guidelines. Nature Agency, Danish Ministry of the Environment, Copenhagen. http://www.klimatilpasning.dk/media/598918/klimat ilpasningsvejledning web.pdf (Accessed 29 February 2016).

29. Jebens, M. (2013). Reducing flood risk as a consequence of climate change or variability. A case study of Vejle and Korsør, Denmark. Unpublished Master Thesis, University of Copenhagen, Denmark.

30. Van den Heuvel, J., Roovers, G. J. and Eijer, M. M. (2011). Multi-Layer Cooperation in Flood Management. How to cooperate within Flood Management in Public area's. Antea Group, The Netherlands.

31. UNISDR. Definitions of terminology. The United Nations Office for Disaster Risk Reduction (unisdr.org).

http://www.unisdr.org/files/26462 8.annex2andacro nyms.pdf (Accessed 29 February 2016).

32. Personal communication with Gert Laursen, Municipality of Odense, Denmark, 2 October 2015.

33. World Bank (2012): Cities and Flooding. A guide to Integrated Urban Flood Risk Management for the 21st Century. The International Bank for Reconstruction and Development report. 638p. 